\title{
An Examination of the Disruptive Innovation Paradox: The Application of the Innovators Dilemma to SME's
}

\author{
Tadhg Nagle ${ }^{1}$ and William Golden ${ }^{2}$ \\ ${ }^{1}$ University College Cork \\ ${ }^{2}$ National University of Ireland, Galway
}

\begin{abstract}
Managing strategic contradiction and paradoxical situations has been gaining importance in technological, innovation and management domains. As a result, more and more paradoxical instances and types have been documented in literature. The innovators dilemma is such an instance that gives a detailed description of how disruptive innovations affect firms. However, the innovators dilemma has only been applied to large organisations and more specifically industry incumbents. Through a multiple case study of six eLearning SME's, this paper investigates the applicability of the innovators dilemma as well as the disruptive effects of Web 2.0 on the organisations. Analysing the data collected over 18 months, it was found that the innovators dilemma did indeed apply to SME's. However, inline with the original thesis the dilemma only applied to the SME's established (pre-2002) before the development of Web 2.0 technologies began. Furthermore, the study highlights that the post-2002 firms were also partly vulnerable to the dilemma but were able to avoid any negative effects though technological visionary leadership. In contrast, the pre-2002 firms were lacking this visionary ability and were also constrained by low risk profiles.
\end{abstract}

\section{Introduction}

Increased technological change and global competition have required a need for managers to incorporate and integrate paradoxical thinking into their methodologies (Lewis, 2000). For instance, in the early 1990's IS researchers were drawn towards the productivity paradox, trying to understand the impact of information technology on organisations (Brynjolfsson, 1993). During the same period a number of wider organisational paradoxes were also identified. These included: the "basic unresolved problem" (Levinthal and March, 1993) the "competency trap" (Henderson and Clark, 1990) and "success syndrome" (Tushman and O' Reilly, 1996). The underlying theme in each of these studies highlights the need for IS and business managers alike to fully understand the possible paradoxical effects of their actions, especially if their actions are viewed as best practice by the wider community (Henderson and Clark, 1990; Tushman and O' Reilly, 1996). From this research, a number of frameworks have been developed to help organisations deal with the complexity of paradoxes (Lewis, 
2000). In particular, the "innovators dilemma" is one such framework that focuses on a very specific paradox within the innovation domain (Christensen and Bower, 1996; Christensen, 1997).

\section{Innovation}

The study of innovation has evolved as a multidisciplinary endeavour with numerous innovation types and definitions existing across many studies (Ettlie et al., 1984; Garcia and Calantone, 2002). The idea that there are different forms of innovation with different competitive effects was first raised by Schumpeter (1942) through his notion of "creative destruction". Later termed as Schumptererian rents, Schumpeter described how value was appropriated from risky initiatives and entrepreneurial insights in uncertain and complex environments, which are subject to self-destruction as knowledge diffuses (Schumpeter, 1934). Following on from Schumpeter, the literature characterised different kinds of innovation based on their impact on the established capabilities of an organisation (Henderson and Clark, 1990). Disruptive innovation is one such form that has drawn the attention of both academics and practitioners alike, as being important in the long-term survival of an organisation (Linton, 2002; Danneels, 2004). Similar to what was termed as "Schumpterian shocks" (Barney, 1991), a disruptive change is one that changes the bases of competition by altering the performance metrics on which firms compete (Danneels, 2004). Initially, the disruptive nature of innovations was very loosely defined but it was later refined by Danneels (2004). He stated that a disruptive change was one that changes the bases of competition by altering the performance metrics on which firms compete. Moreover, research in the domain, such as: the phases of evolution of disruptive technologies (Myers et al., 2002), predictive models of disruptive innovation market diffusion (Linton, 2002), the definition of disruptive innovation and disruptive technologies (Danneels, 2004; Markides, 2006), have all added to the academic understanding and debate within the area.

\section{ELearning and Disruptive Innovation}

An example of the disruptive effects of innovation can be clearly seen in the eLearning industry. In 2006 a report highlighted that the industry was experiencing the disruptive impact of Web2.0 with the development of eLearning 2.0 (TerKeurst et al., 2006). The term Web 2.0, which refers to the use of the internet to increase creativity, information sharing and collaboration between users, was officially coined in 2005 by O'Reilly. These concepts have led to the development and evolution of web-based communities and hosted services using platforms such as: socialnetworking sites, wikis, blogs, and folksonomies (O' Reilly, 2005). As an indication of how fast Web 2.0 was gaining traction in the IT industry, Facebook (a social network platform) was valued at $\$ 100$ million after a mere 18 months of operation (Eisenmann and Feinstein, 2008).

The first of three findings from the 2006 eLearning report found Web2.0 to be at the core of many developments in eLearning. In addition, it estimated that $80 \%$ of 
learning is done informally compared to $20 \%$ of formal and structured learning (TerKeurst et al., 2006). The later defining learning through defined courses or pedagogically defined methods, with the former defining learning through informal settings, conversations with peers or pedagogically undefined events (Cross, 2007). The potential for the web 2.0 technologies was thus seen supporting this new mode of eLearning as it moved from the distribution of formal content to a more learner centric environment (TerKeurst et al., 2006). Examples of the effects of Web 2.0 on the wider eLearning industry are quite visible. In 2005, Wikipedia passed 750,000 articles (Wikipedia, 2008). Even though it has received mixed reviews, its popularity and ability to democratise information is quite unique (Korfiatis et al., 2006). Furthermore, that year the "OpenCourseWare Consortium" was formed. The OpenCourseWare Consortium now consists of more than 200 higher education institutions and associated organisations from around the world. The primary aim of the consortium is to create a broad and deep body of open educational content using a free-sharing model. The possible effect of this is striking when Massachusetts Institute of Technology (MIT) openly admit that it costs them between $\$ 10,000$ $\$ 30,000$ to publish a course through OpenCourseWare and in total costs $\$ 4$ million a year to support the initiative.(OCW, 2008). In addition, Web 2.0 technologies have been supported by the rise of mobile and ubiquitous computing, which further disrupts the eLearning industry (Hall and Bannon, 2006; Clough et al., 2008).

\section{Innovators Dilemma}

From a paradoxical perspective the innovators dilemma further adds to the domain of disruptive innovation. In essence, the innovators dilemma highlights the vulnerability of large industry incumbents when faced with a disruptive innovation in the form of a disruptive technology. An issue documented by many authors (McDermott and O'Connor, 2002), Christensen posits that the primary cause for the vulnerability lies in strong management paradigms that direct organisations to blindly focus on their current customers while ignoring innovations or technologies that appear inferior with potentially low financial returns (Christensen, 1997; Christensen and Raynor, 2003; Tellis, 2006). The dilemma then arises when the technology quickly outperforms current technologies leaving the large industry incumbents at a competitive disadvantage with a strong risk of loosing their current customers (Christensen, 1997).

Giving such examples of the mechanical excavator and hard disk drive industry, Christensen demonstrated how managers ignored new technologies which were economically unfeasible but later went on to become the underlying technologies of their markets. He found that organisations with technological leadership in an industry, tended to fall into the trap of aggressively pursuing high returns on innovations. This trap is indicative of the rule of thumb for only choosing product line extensions that promise to yield a higher net price (Calthrop, 2007). The fear is that if organisations do not follow this rule they may find themselves in the same situation as Hoover. Dyson entered the US market when Hoover was "innovating downward with simpler, cheaper products, reducing prices so that it could maintain its share of unit sales". Consequently Dyson gained the dollar share of the US market (Calthrop, 2007). However, avoiding a similar fate as befell Hoover by pursuing a long-term 
strategy of improving an existing product to further fulfil customer requirements, does not guarantee success. Such a course of action may lead to a situation wherein when the improved product is superseded by another technology, the organisation is unable to respond. The dilemma which lies in developing competing technologies at a time when the dominant market technology is currently and successfully employed by an organisation is a contradiction in managerial terms. This paradox is further defined through the five principles of the innovators dilemma, which have been further utilized in researching the phenomenon (Dhillion et al., 2001). The principles explicitly specify key characteristics of a disruptive technological shift that cause large organisations to fail, which include:

Which explicitly specified key characteristics of a disruptive technological shift cause large organisations to fail? These principles include:

1. Companies depend on customers and investors for resources

2. Small markets don't solve the growth needs of large companies

3. Markets that don't exist can't be analysed

4. An organisation's capabilities define its disabilities

5. Technology supply may not equal market demand

Even though the theory has been supported by a number of authors such as Nault and Vandenbosch (2000), it has also had its critics (Danneels, 2004; Markides, 2006; Tellis, 2006). However, each of the critiques highlighted the complexity of the domain and the positive effect that research has made to the area. For instance, Danneels (2004) outlined a number of pitfalls in the theory (eg its ineffective predictive nature) but also highlighted its ability to "offer a really intricate picture of how firms react to technological shifts" and added to the theory by more tightly defining a disruptive innovation. Markides (2006) posited the need for a refined definition of disruptive innovations (to include (i) technologies, (ii) business models, and (iii) processes), but also stated that these three sub-categories may have the same effect on markets as outlined by Christensen. Finally, Tellis (2006) noted that the success and failure of an organisation is not determined by external impacts such as disruptive technologies, but by internal factors such as the culture of the firm. However, Christensen's theory does weigh heavily on the internal aspects of the firm as one of his key findings is that good management techniques are paradoxically the source of vulnerability and inertia in the face of disruptive innovations. As already outlined, the innovators dilemma specifically deals with large organisations with specific emphasis on incumbents. Nonetheless, the question arises; does the innovators dilemma also apply to other types of organisations? So far the debate has revolved around defining the different aspects of the theory with a distinct absence of research outside of these parameters. To this end the research question posited by this paper states:

RQ: Within the context of the eLearning industry, does the innovators dilemma apply to organisations other than large industry incumbents? 


\section{Research Method}

The primary data of the study is collected through a multiple case study approach incorporating six eLearning organisations operating in Ireland. The study was categorised as exploratory due to the scarcity of empirical work in the area, the focus on discovery, and the aim of theory building. A number of authors have proposed that case studies constitute a suitable research methodology for exploratory research of this kind (Yin, 1984; Marshall and Rossman, 1989). The researchers also decided that a multiple case study would be the most appropriate method for this study as it would facilitate the collection of data from a larger number of organisations, and would form the basis for more focused research at a later stage. Moreover, case studies allow the study of phenomena in their proper contexts.

Highlighting the relevant context of the study, each of the organisations in the multiple case study were a part of an innovation network funded by Enterprise Ireland. Having identified eLearning as a high potential sector within the Irish economy (Forfás, 2002), Enterprise Ireland, a government body for supporting indigenous start-ups and SME's enabled an existing network of eLearning firms to gain access to substantial R\&D resources. Each of the organisations in the study fell under the SME categorisation. Ranging in size from under 10 employees to between 100 and 150 employees, the SME's had also revenues of up to $€ 15$ million around that period. In addition, all of the organisations were primarily involved in the eLearning industry on a European and/or global basis and had been in existence between 2 and 20 years.

In 2006 and with the support of $€ 2.5$ million in funding, the organisations developed an innovation partnership with a third level institution, which specialised in Web 2.0 and semantic technologies. As a member of the third level institution the researcher was able to collect primary data over the first 18 months of innovation network, in which the eLearning SME's faced the technological disruption of Web 2.0. In all over 70 hours of primary data was collected from multiple sources and multiple informants using interviews and participant observation. Data was gathered from each of the eLearning organisations as well as the third level institution and Enterprise Ireland. In total, 7 interviews were undertaken, which lasted between 45 90 minutes and were all semi-structured. Participant observation was used throughout the 18 months and data was also gained from inter-organisational meetings and open days. Even though the meetings were not as formalised as interviews, the researcher was able to collect required data by asking questions or noting points of information that addressed the questions asked in previous interviews. Furthermore, on more than one occasion, meetings were conducted over a full business day. This gave the researcher time to talk freely with company employees and collect data in an unstructured manner that aligned with the research objectives of the study. Open days also consisted of one to two day events where all of the organisations in the innovation network were invited to one location to discuss current issues and topics associated with the network. Finally, analysis of company/industry reports and press releases that applied to period and organisations in question were also used to triangulate data used in the study. This data was then analysed through meta-matrices structured by the principles of the innovators dilemma. This enabled cross case comparisons as well as identification of common themes within the study. 


\section{Findings}

Analysing the data gathered in the study, it became apparent that within the six organisations, two categories of firms existed. The first category, which was made up of the four firms (Companies A, B, C, D) established pre-2002 (before the beginning of Web 2.0) had done little to analyse, understand or deal with the technological shift in the industry. For instance the CTO of Company D saw very little change in the eLearning industry stating that "courseware was much the same as it was 20 years ago".

Further evidence indicative of the inertia which the pre-2002 firms were experiencing was collected during an interview with a CTO of Company A. During this interview the CTO stated that "we (Company A) don't have systems that are in any way sympathetic to where the web is. We are as much about Web1.0, big system in the sky with content. The content is multimedia and very engaging but there is no community, there is no collaboration, no sharing of content, in short, there is no Web2.0".

In contrast, the second category of organisations was made up of the two organisations that were established post-2002 and around the time that Web 2.0 technologies began to develop (Companies E and F). Taking the disruptive effects of ubiquitous computing as an underlying driver of the Web 2.0 technological shift in the eLearning industry, Company $\mathrm{F}$ had developed a product that would position them as an enabler of mobile eLearning by leveraging existing LMS resources. Company $\mathrm{E}$, the organisation that made up the rest of the post-2002 category continued to use the advances in software and content delivery to their advantage. As an indication of how they were using Web2.0 to their advantage, the CTO stated that their biggest objective (early 2006) was to "create a community around" their product. This dichotomous classification of the pre and post-2002 firms is in line with Christensen and Bower's (1996) categorisation of existing and entrant organisations. In addition, the initial analysis is also in line with the thesis. However, to further explore the research question and determine whether the innovators dilemma applies to SME's, each of the firms are investigated in more detail using the five principles set out by Christensen.

\section{Principle \#1: Companies depend on customers and investors for resources}

Evidence taken from each of the pre-2002 firms depicted in Table 1, explicitly demonstrates their over dependence on current customers for resources and innovation direction. All innovation efforts were primarily focused on getting extra value from current customers. For instance, the COO of Company A stated that they would rather gain more revenue off existing customers then look for new customers. In addition, in-line with the Theory of resource dependence from which this principle is based, the CEO of Company $\mathrm{C}$ highlighted that it is customers that control what type of technology an organization explores. Moreover, evidence from Company D illustrated that the process of exploration only went as far as the current customers of the organisation. Furthermore, evidence from a senior member in Enterprise Ireland suggested that innovation initiatives that did not intend to generate revenue from their current customers within the short-to-medium term meant too much high risk for the 
Table 1. Data demonstrating the dependence on customers for resources

\begin{tabular}{|l|l|l|}
\hline Quote & Interviewee & Company \\
\hline $\begin{array}{l}\text { "Rather than worry about solving a new problem for a new client. I } \\
\text { much rather double the amount of money each client pays me every } \\
\text { year then going out to find the same number customers paying me the } \\
\text { same amount every year" }\end{array}$ & COO & $\begin{array}{l}\text { Company A } \\
\text { Pre-2002 }\end{array}$ \\
\hline $\begin{array}{l}\text { Talking about the next generation of customer and user of eLearning it } \\
\text { was highlighted "that they are geared to think". The CTO added "yes } \\
\text { but this generation pays the cheque". }\end{array}$ & CTO & $\begin{array}{l}\text { Company B } \\
\text { Pre-2002 }\end{array}$ \\
\hline $\begin{array}{l}\text { "clients push the technology in a very tight market" } \\
\text { "We typically start off by researching the market or from demand from } \\
\text { clients. As for the financial sector there maybe a new derivative } \\
\text { product on the market and a client might need" }\end{array}$ & CEO & COO \\
\hline $\begin{array}{l}\text { "In terms in overall product direction, probably not an awful lot at the } \\
\text { moment as it is ahead of the curve, they haven't seen it before" }\end{array}$ & COO & $\begin{array}{l}\text { Company D } \\
\text { Pre-2002 }\end{array}$ \\
\hline
\end{tabular}

eLearning SME's to manage. This limitation in-turn put a big restriction on their ability to look beyond their existing market or existing customers. In contrast, the post-2002 firms were in process of building a customer base and were not strongly dependent on existing customers. In addition, input from customers in the development of their products was minimal. Moreover, during an interview the COO of one of the post-2002 firms stated the input that was received was not of great use as "they (customers) haven't seen it before".

\section{Principle \#2: Small markets don't solve the growth needs of large companies}

With particular emphasis on eLearning 2.0 and mobile Learning, Table 2 highlights that the pre-2002 firms felt the markets were too small for them. For instance, Company C felt that the potential market constituted of "geeks" alone. These could be viewed as early adopters and as potential lead users. However, the pre-2002 firms viewed this type of market as low demand and low value, which highlights a lack of vision. Demonstrating this point, the CTO of Company D felt that this new type of eLearning 2.0 could be compared to "dumpster diving". The markets were also small for the post-2002 firms but as they were in the early growth stages of organisational development. There was a sufficiently large enough market for them to survive. In the case of Company E, they used venture capital to cover any shortfalls due to the lack of demand from the emerging markets.

Table 2. Data demonstrating the applicability of principle two to the SME's

\begin{tabular}{|l|l|l|}
\hline Quote & Interviewee & Company \\
\hline $\begin{array}{l}\text { "all you have is the geeks that love blogging and write all the time" } \\
\text { "we have to develop ourselves to make it normal to read an email off a } \\
\text { blackberry. People are only coming to that and there is not that much } \\
\text { demand for it." }\end{array}$ & CTO & $\begin{array}{l}\text { Company C } \\
\text { Pre-2002 }\end{array}$ \\
\hline $\begin{array}{l}\text { Company C } \\
\text { Pre-2002 }\end{array}$ \\
\hline "we have come from start-up stage to initial growth stage" & CTO & $\begin{array}{l}\text { Company D } \\
\text { Pre-2002 }\end{array}$ \\
\hline
\end{tabular}




\section{Principle \#3: Markets that don't exist can't be analysed}

Indicative of the organisations in its category, Company A primarily did market analysis on their current customers (as highlighted in Table 4). In addition, the majority of the data analysed points to the fact that very little market analysis was carried out beyond the scope of their market segments. In fact there is evidence to suggest that the organisations felt that trying to analyse future markets was of no benefit. The clearest indication of this futility experienced by organisations was given by a partner of Company B during a meeting. The partner felt that an organisation should not look too much far ahead as the potential for generating revenue is primarily in the short-term future. The partner states that analysis only works when you go "one and a half steps ahead" compared to "ten and a half steps ahead". Moreover, the quote from Company $\mathrm{C}$ indicates that the organisation did not have the ability to envision a future for technologies (such as mobile computing) within eLearning. This is in contrast to Company $\mathrm{F}$ of the post-2002 firms who saw big potential in the technology and developed a project around it. In addition, both of the post-2002 firms had quite clear visions of the future of the eLearning industry. As already mentioned, Company $\mathrm{F}$ viewed mobile computing to be a big driver within the industry, whereas Company E saw the industry being disruptive by Web 2.0. Furthermore, it was not just Web 2.0 social networking but "social networking in an Enterprise sense" (COO, Company E). What this shows is that the post-2002 organisations faced the same hurdles in analysing the future eLearning markets, but were better able to create a clear vision around where their organisation could utilise the potential of new technologies.

Table 3. Data demonstrating difficulties experienced by the organisations in analysing new markets

\begin{tabular}{|l|l|l|}
\hline Quote & Interviewee & Company \\
\hline $\begin{array}{l}\text { "My management team spends a lot of time in the } \\
\text { field and detects a pattern in the market place and } \\
\text { says something like our customer base could do } \\
\text { with something that does this." }\end{array}$ & & \\
\hline $\begin{array}{l}\text { "I have lived my life ten and a half steps ahead of } \\
\text { the market, what I have learned is to make money } \\
\text { you can only be one and a half steps ahead" }\end{array}$ & Partner & $\begin{array}{l}\text { Company B } \\
\text { Pre-2002 }\end{array}$ \\
\hline $\begin{array}{l}\text { "A lot of people are talking about m-learning or } \\
\text { learning on PDA's. I don't see it happening yet, I } \\
\text { still think there is too much to do for a person to do } \\
\text { a course on their PDA". }\end{array}$ & & \\
\hline & CTO & $\begin{array}{l}\text { Company C } \\
\text { Pre-2002 }\end{array}$ \\
\hline social networking in an Enterprise sense" & COO & $\begin{array}{l}\text { Company E } \\
\text { Post-2002 }\end{array}$ \\
\hline
\end{tabular}

\section{Principle \#4: An organisation's capabilities defines its disabilities}

Throughout the 18 month study it was found that the core competence of the pre-2002 organisations lay in fulfilling the regulatory/compliance needs of their customers by producing eLearning courses. In addition, as the data (see Table 4) demonstrates, the 
main capabilities of these firms leaned more towards customer relationship management than technological expertise. For instance the COO from Company A explicitly stated that their core competence was their Sales department. The CEO of Company D also noted that in the competitive market of eLearning, their organisation strength lay in knowing their market. However, the strongest evidence of the shift away from a technological emphasis can be found in Company $\mathrm{C}$, where the CEO admitted that he consistently chose short-term revenue opportunities over technological R\&D investment. In contrast, both of the post-2002 firms were not tied to the compliance/regulation market. Furthermore, they both believed that the compliance/regulation market was at the low end of the value scale. In addition, their capabilities were strongest on the technological aspect and as a result they found it easier to take advantage of the new technological trends emerging. As a result their existing capabilities did not tie them to specific markets or specific technologies.

Table 4. Data demonstrating the different impacts of the pre and post-2002 firm's capabilities

\begin{tabular}{|l|l|l|}
\hline Quote & Interviewee & Company \\
\hline $\begin{array}{l}\text { "Its not the customisability of our products but the } \\
\text { fact that we can produce a custom built product for } \\
\text { whatever the need is." }\end{array}$ & $\begin{array}{l}\text { Company C } \\
\text { Pre-2002 }\end{array}$ \\
\hline $\begin{array}{l}\text { Asked what is the core competence of the firm the } \\
\text { COO "I'm always going to say sales" }\end{array}$ & COO & $\begin{array}{l}\text { Company A } \\
\text { Pre-2002 }\end{array}$ \\
\hline $\begin{array}{l}\text { "We are very good at keeping a close eye on our } \\
\text { niche and knowing our customers" }\end{array}$ & CEO & $\begin{array}{l}\text { Company D } \\
\text { Pre-2002 }\end{array}$ \\
\hline $\begin{array}{l}\text { "The CTO has always shown the need for an R\&D } \\
\text { department but I always say that we need to make } \\
\text { money" (CEO) }\end{array}$ & CEO/CTO & $\begin{array}{l}\text { Company C } \\
\text { Pre-2002 }\end{array}$ \\
\hline $\begin{array}{l}\text { "value in certification. Certification as it is now is } \\
\text { nothing but a set of multiple choice questions". }\end{array}$ & COO & $\begin{array}{l}\text { Company E } \\
\text { Post-2002 }\end{array}$ \\
\hline $\begin{array}{l}\text { "Compliance has driven eLearning but that is not } \\
\text { where the future of the industry lies" }\end{array}$ & $\begin{array}{l}\text { Company F } \\
\text { Post-2002 }\end{array}$ \\
\hline
\end{tabular}

\section{Principle \#5: Technology supply may not equal market demand}

There is strong evidence that suggests that both the current and new technologies within the industry were overshooting the need of the organisations customers of both the pre and post-2002 firms. Furthermore, table 5 illustrates that the pre-2002 firms were struggling to balance the technological oversupply within their current products with the weak demand for newer technologies. The CTO of Company $\mathrm{C}$ pointed out that there are excellent technologies available to support social networking and collaboration. However, this was of no value if there was no demand for the technology and number of people collaborating was none. Indicative of all the firms, the COO of Company A explicitly stated that the technology was "way ahead of the market". However, instead of just staying away from new technologies, the post-2002 firms took it upon themselves to "educate the market" (CTO, Company F). In addition, Company E used new business models to drive the adoption of their new eLearning product. 
Table 5. Data demonstrating that technology supply in the eLearning industry did not meet the demand of both types of firms

\begin{tabular}{|c|c|c|}
\hline Quote & Interviewee & Company \\
\hline $\begin{array}{l}\text { Semantic web and stuff..... yea, we don't see the } \\
\text { value in it yet as customers haven't asked for it. }\end{array}$ & $\mathrm{COO}$ & $\begin{array}{l}\text { Company D } \\
\text { Pre-2002 }\end{array}$ \\
\hline $\begin{array}{l}\text { "Wisdom of crowds is useless if you're the only } \\
\text { one there" }\end{array}$ & CTO & $\begin{array}{l}\text { Company B } \\
\text { Pre-2002 }\end{array}$ \\
\hline $\begin{array}{l}\text { "There is all the great stuff that we can do for } \\
\text { customers, multiple ways of delivering content, if } \\
\text { wake up in the morning and decide to take the } \\
\text { train to work they can get it on their phone and } \\
\text { when they get into the office they can carry on } \\
\text { with their PC. But from my point of view is who is } \\
\text { going to pay for the extra layers" }\end{array}$ & CTO & $\begin{array}{l}\text { Company C } \\
\text { Pre-2002 }\end{array}$ \\
\hline $\begin{array}{l}\text { "The technology is way ahead of what the market } \\
\text { can bare and what the market will pay for and we } \\
\text { have to run a business and the business is a slave } \\
\text { to the market." }\end{array}$ & $\mathrm{COO}$ & $\begin{array}{l}\text { Company A } \\
\text { Pre-2002 }\end{array}$ \\
\hline "I find myself educating the market" & CTO & $\begin{array}{l}\text { Company F } \\
\text { Post-2002 }\end{array}$ \\
\hline $\begin{array}{l}\text { "we are evangelising, going out getting in front } \\
\text { of users, telling them what you do." }\end{array}$ & $\mathrm{COO}$ & $\begin{array}{l}\text { Company E } \\
\text { Post-2002 }\end{array}$ \\
\hline
\end{tabular}

\section{Summary of Findings}

Summarising the applicability of the innovators dilemma to the SME's in the study, Table 6 demonstrates that the pre-2002 firms were caught in the dilemma. Moreover, in the case of the pre-2002 firms, their inability to handle medium to long-term risks placed strong restrictions on their ability to reduce their dependence on current customers and invest in Web 2.0 innovations. Highlighted in Table 6, only two of the principles could be adequately applied to the post-2002 firms. However, their ability to create a clear vision and the realisation of their role in educating the market helped

Table 6. Summary of the applicability of the Innovators Dilemma to the pre and post-2002 firms

\begin{tabular}{|c|c|c|c|c|c|}
\hline & \multicolumn{5}{|c|}{ Principles of the Innovators Dilemma } \\
\hline & $\# 1$ & $\# 2$ & \#3 & $\# 4$ & \#5 \\
\hline Pre-2002 & Applied & Applied & Applied & Applied & Applied \\
\hline $\begin{array}{l}\text { Post- } \\
2002\end{array}$ & $\begin{array}{l}\text { Did not apply as (i) } \\
\text { the organisations } \\
\text { were building a } \\
\text { customer base, and } \\
\text { (ii) due to the } \\
\text { novelty of their } \\
\text { products had } \\
\text { minimal input from } \\
\text { customers. }\end{array}$ & $\begin{array}{l}\text { Did not apply as (i) } \\
\text { the firms were in an } \\
\text { early growth stage } \\
\text { and the small markets } \\
\text { were sufficient, (ii) } \\
\text { venture capital } \\
\text { enabled the firms to } \\
\text { build up small } \\
\text { markets }\end{array}$ & Applied & $\begin{array}{l}\text { Did not apply as } \\
\text { the capabilities of } \\
\text { firms worked to } \\
\text { their advantage } \\
\text { rather than } \\
\text { disadvantage when } \\
\text { exploiting the } \\
\text { disruptive } \\
\text { innovations }\end{array}$ & Applied \\
\hline
\end{tabular}


the firms overcome the negative consequences of the principles. This ability to create a vision was clearly lacking in the pre-2002 firms. In addition, Table 6 also highlights the reasons why principles 1,2 and 4 did not apply to the organisations.

\section{Conclusions}

Christensen specifically focuses on large and successful organisations in his research to highlight the discontinuous nature of disruptive innovations. In doing so, he highlights that one of the causes of innovation inertia is the size of the organisation, but fails to analyse any organisation falling within the SME categorisation. For instance, principle two of the innovators dilemma states that "small markets don't solve the growth needs of large organisations". However, evidence from our findings demonstrates that all five principles of the innovators dilemma apply to SME's just as they apply to large organisations in the face of disruptive innovations. In particular, it was found that the dilemma only applied to the pre-2002 firms. This is inline with the dilemma and further emphasises the relevance of the paradox to incumbent or established firms in comparison to start-ups or new market entrants. However, the issue of risk and the risk profile of firms played a much bigger role than was documented by Christensen. This would support research that shows a positive link between resource availability and risk-taking, which in-turn impacts the innovativeness of an organisation (Entrialgo et al., 2001).

The findings also highlighted that the post-2002 firms were able to avoid the negative effects of principle 3 (markets that don't exist cannot be analysed) by creating a clear vision of potential opportunities in the industry and by working towards making those visions a reality. This was done by both post-2002 firms as they went about evangelising and educating the market. These findings bring further light to bear on how "visionary leadership that embraces change" (Tellis, 2006), can be used to manage the disruptive paradox.

Overall, the study shows that SME's are not different from large business units (Lubatkin et al., 2006) in their need to overcome organisational and innovation challenges. This further suggests that SME's are just as susceptible to innovation inertia and disruptive technologies as large organisations and also forges a link between the general corpus on innovation and literature on SME innovation, which is currently lacking in research (Edwards et al., 2005).

\section{References}

Barney, J.: Firm Resources and Sustained Competitive Advantage. Journal of Management 17, 99-120 (1991)

Brynjolfsson, E.: The Productivity Paradox of Information Technology. Communications of the ACM 36, 67-77 (1993)

Calthrop, P.: Higher Net Price-Or Bust. Harvard Business Review 85, 30 (2007)

Christensen, C.: The innovator's dilemma: when new technologies cause great firms to fail. Business School Press, Boston (1997)

Christensen, C.M., Bower, J.L.: Customer power, strategic investment, and the failure of leading firms. Strategic Management Journal 17, 197-218 (1996) 
Christensen, C.M., Raynor, M.E.: The Innovator's Solution. Creating and Sustaining Successful Growth. Harvard Business School Press, Boston (2003)

Clough, G., Jones, A.C., McAndrew, P., Scanlon, E.: Informal learning with PDAs and smartphones. Journal of Computer Assisted Learning 24, 359-371 (2008)

Cross, J.: Informal Learning: Rediscovering the Natural Pathways That Inspire Innovation and Performance. Pfeiffer, San Francisco (2007)

Danneels, E.: Disruptive technology reconsidered: A critique and research agenda. Journal of Product Innovation Management 21, 246-258 (2004)

Dhillion, G., Coss, D., Hackney, R.: Interpreting the role of disruptive technologies in ebusiness. Logistics Information Management 14, 163-171 (2001)

Edwards, T., Delbridge, R., Munday, M.: Understanding innovation in small and medium-sized enterprises: a process manifest. Technovation 25, 1119-1127 (2005)

Eisenmann, T.R., Feinstein, B.: Harvard Business School, pp. 1-30 (2008)

Entrialgo, M., Fernandez, E., Vazquez, C.J.: The effect of the organizational context on SME's entrepreneurship: Some Spanish evidence. Small Business Economics 16, 223-236 (2001)

Ettlie, J.E., Bridges, W.P., Okeefe, R.D.: Organization Strategy and Structural Differences for Radical Versus Incremental Innovation. Management Science 30, 682-695 (1984)

Forfás: A Strategy for the Digital Content Industry in Ireland (2002)

Garcia, R., Calantone, R.: A critical look at technological innovation typology and innovativeness terminology: a literature review. Journal of Product Innovation Management 19, 110-132 (2002)

Hall, T., Bannon, L.: Designing ubiquitous computing to enhance children's learning in museums. Journal of Computer Assisted Learning 22, 231-243 (2006)

Henderson, R.M., Clark, K.B.: Architectural Innovation - the Reconfiguration of Existing Product Technologies and the Failure of Established Firms. Administrative Science Quarterly 35, 9-30 (1990)

Korfiatis, N.T., Poulos, M., Bokos, G.: Evaluating authoritative sources using social networks: an insight from Wikipedia. Online Information Review 30, 252-262 (2006)

Levinthal, D.A., March, J.G.: The Myopia of Learning. Strategic Management Journal 14, 95 112 (1993)

Lewis, M.W.: Exploring paradox: Toward a more comprehensive guide. Academy of Management Review 25, 760-776 (2000)

Linton, J.D.: Forecasting the market diffusion of disruptive and discontinuous innovation. IEEE Transactions on Engineering Management 49, 365-374 (2002)

Lubatkin, M.H., Simsek, Z., Ling, Y., Veiga, J.F.: Ambidexterity and performance in small- to medium-sized firms: The pivotal role of top management team behavioral integration. Journal of Management 32, 646-672 (2006)

Markides, C.: Disruptive innovation: In need of better theory. Journal of Product Innovation Management 23, 19-25 (2006)

Marshall, C., Rossman, B.G.: Designing Qualitative Research. Sage Publications, Newbury Park (1989)

McDermott, C.M., O’Connor, G.C.: Managing radical innovation: an overview of emergent strategy issues. Journal of Product Innovation Management (2002)

Myers, D.R., Sumpter, C.W., Walsh, S.T., Kirchhoff, B.A.: A practitioner's view: Evolutionary stages of disruptive technologies. IEEE Transactions on Engineering Management 49, 322 329 (2002)

Nault, B.R., Vandenbosch, M.B.: Research report: Disruptive technologies - Explaining entry in next generation information technology markets. Information Systems Research 11, 304 319 (2000) 
O’ Reilly, T.: vol. 2008. O’ Reilly, CA (2005),

http://www. oreillynet.com/pub/a/oreilly/tim/news/2005/09/30/

what-is-web-20.html

OCW, vol. 2008 (2008),

http: / /www. ocwconsortium.org/about-us/about-us.html

Schumpeter, J.A.: The Theory of Economic Development: An Inquiry into Profits, Capital, Credit, Interest, and the Business Cycle. Harvard University Press, Cambridge (1934)

Schumpeter, J.A.: Capitalism, Socialism and Democracy. Havard University Press, Cambridge (1942)

Tellis, G.J.: Disruptive technology or visionary leadership? Journal of Product Innovation Management 23, 34-38 (2006)

TerKeurst, J., Keith, A., Hyland, L., Bull, G., Mackenzie, E., Woolard, A., Turner, S.: DTI and University of Abertay Dundee (2006)

Tushman, M.L., O' Reilly, C.A.: Ambidextrous organizations: Managing evolutionary and revolutionary change. California Management Review 38, 8 (1996)

Wikipedia (2008), http: / / en.wikipedia.org/wiki /History_of_Wikipedia

Yin, R.K.: Case Study Research: Design and Methods. Sage Publications, Beverly Hills (1984) 